\title{
Peningkatan Kompetensi Guru dalam Mengintegrasikan HOTS (Higher Order Thinking Skills) Pada Pembelajaran
}

\author{
Umi Hanik $^{1}$, Isna Ida Mardiyana ${ }^{1}$, Abdul Rosid ${ }^{2}$ \\ ${ }^{1}$ Prodi Pendidikan Guru Sekolah Dasar, ${ }^{2}$ Prodi Pendidikan Bahasa Indonesia \\ Universitas Trunojoyo Madura \\ E-mail : umi.hanik@trunojoyo.ac.id
}

DOI: https://doi.org/10.21107/pangabdhi.v6i1.7101

Naskah diterima 21 Februari 2020, Revisi 11 April 2020, Terbit 19 April 2020

\begin{abstract}
Abstrak
Salah satu masalah dalam pelaksanaan kurikulum 2013 adalah terkait pengintegrasian keterampilan berpikir tingkat tinggi atau HOTS (Higher Order Thinking Skills) dalam pembelajaran. Tujuan kegiatan ini adalah untuk memberikan pelatihan dan pendampingan kepada guru-guru khususnya di jenjang sekolah dasar. Metode yang digunakan yaitu, 1) tahap pra pelaksanaan kegiatan: wawancara dan observasi, dan 2) tahap pelaksanaan kegiatan: ceramah, tanya jawab, praktek, dan 3) tahap pasca pelaksanaan kegiatan: pendampingan intensif secara online melalui grup whatsapp . Kegiatan ini diikuti oleh guru-guru di Kecamatan Klampis, Kecamatan Sepulu dan Kecamatan Tanjung Bumi yang lokasi sekolahnya berada dalam wilayah penempatan KKN (Kuliah Kerja Nyata) yakni berada di beberapa desa di Kecamatan Klampis, Sepulu dan Tanjung Bumi. Struktur materi yang diberikan adalah 1) pemantapan kurikulum 2013, 2) pembelajaran berbasis HOTS, 3) penyusunan soal berbasis HOTS, 4) pengembangan perangkat pembelajaran berbasis HOTS. Hasil kegiatan ini adalah peserta berhasil: 1) meningkatkan pemahaman tentang kurikulum 2013 dan pembelajaran berbasis HOTS, 2) menyusun soal berbasis HOTS, dan 3) mengembangkan perangkat pembelajaran berbasis HOTS.
\end{abstract}

Kata Kunci : kurikulum 2013, keterampilan berpikir tingkat tinggi, perangkat pembelajaran

\begin{abstract}
One of the problems in implementing the 2013 curriculum is related to the integration of higher order thinking skills (HOTS) in learning. The purpose of this activity was to provide training and assistance to teachers, especially at the elementary school level. The methods used some stage, first, the stage of preimplementation activity that consisted of interview and observation, second, the stage of implementation activity that consisted of lecture, question and answer, practice, and third, the stage of postimplementation activity that consisted of intensive online mentoring by the group whatsapp. This activity was joined by teachers where the locations of the schools were in KKN (Community Service Program) placement area. Those schools were in several villages in Klampis, Sepulu and Tanjung Bumi Sub-Districts. The structure of the material provided is: 1) strengtheing of the 2013 curriculum, 2) learning based on HOTS, 3) drafting problems based on HOTS, and 4) development of learning devices based on HOTS. The result of this activity was that the participants succeeded in: 1) enhance understanding of the 2013 curriculum and learning based on HOTS, 2) drafting problems based on HOTS, and 4) drafting the learning devices based on HOTS.
\end{abstract}

\section{Key Words : 2013 curriculum, Higher Order Thinking Skills, learning devices}

\section{PENDAHULUAN}

Dalam beberapa dekade, Indonesia telah mengalami beberapa perubahan kurikulum. Terhitung mulai periode setelah kemerdekaan ada 10 kali perubahan kurikulum, yakni 1) Rencana Pelajaran tahun 1947; 2) Rencana Pelajaran Terurai tahun 1952; 3) Rencana Pendidikan tahun 1964; 4) Kurikulum 1964; 5) Kurikulum 1975; 6) Kurikulum CBSA tahun 1984; 7) Kurikulum 1994; 8) Kurikulum berbasis Kompetensi (KBK) tahun 2004; 9) Kurikulum Tingkat Satuan Pendidikan (KTSP) tahun 2006, dan 10) Kurikulum 2013 (Wahyuni, 2015). Setiap perubahan kurikulum tersebut, pasti dibutuhkan kesiapan-kesiapan diantaranya: 1) kompetensi guru, 2) buku, dan 3) tata kelola untuk mekanisme pembelajaran.

Terkait kompetensi guru, aspek ini yang yang paling penting karena guru sebagai garda terdepan pelaksanaan kurikulum termasuk dalam 
hal ini pelaksanaan kurikulum 2013-yang saat ini sedang diimplementasikan. Kurikulum ini telah berlangsung sekitar lima tahun bagi sekolah-sekolah yang menjadi pilot project. Sedangkan menjadi tahun pertama bagi sekolahsekolah yang siap mengimplementasikannya pada tahun ajaran 2018/2019. Meskipun demikian, belum semua guru siap mengimplementasikan kurikulum 2013 kendati kurikulum ini telah berjalan selama kurang lebih 5 (lima) tahun.

Salah satu unsur dalam aspek kompetensi yang menjadi kendala pada proses pembelajaran adalah kesulitan guru mendorong peserta didik untuk menghasilkan karya kontekstual. Agar peserta didik dapat menghasilkan karya tersebut, harus diimbangi dengan kemampuan guru yang selalu menciptakan pembelajaran kontekstual. Namun hal ini menjadi salah satu masalah dalam implementasi kurikulum 2013, seperti hasil penelitian Subagiyo dan Safrudiannur (2014) bahwasannya salah satu kendala terkait kompetensi guru dalam mengimplementasikan kurikulum 2013 adalah lemahnya kemampuan guru dalam mengembangkan masalah kontekstual khususnya dalam pembelajaran tematik di sekolah dasar.

Dalam pembelajaran kontekstual, salah satu komponen yang harus ada adalah berpikir kritis dan kreatif (Johnson, 2002). Siswa dilatih untuk memanfaatkan berpikir kritis dan kreatifnya dalam pengumpulan, analisis dan sintesis data, memahami suatu isu atau fakta dan pemecahan masalah sehingga dalam hal ini siswa juga dilatih untuk selalu berpikir dalam taraf yang optimal. Berpikir pada taraf yang optimal ini bisa disebut sebagai keterampilan berpikir tingkat tinggi atau Higher Order Thinking Skill (HOTS). Heong, et al (2011) mengatakan bahwa, "higher order thinking is using the thinking widely to find new challenge. Higher order thinking demands someone to apply new information or knowledge that he has got and manipulates the information to reach possibility of answer in new situation". Berpikir tingkat tinggi menggunakan pemikiran secara luas untuk menemukan tantangan baru. Pemikiran tingkat tinggi menuntut seseorang untuk menerapkan informasi atau pengetahuan baru yang dia dapatkan dan memanipulasi informasi untuk mencapai kemungkinan jawaban dalam situasi baru.

Sejalan dengan hal tersebut, Siswono (2018) juga mengatakan bahwa HOTS berorientasi pada kemampuan berpikir kritis dan kreatif.
Kemampuan tersebut merupakan salah satu kemampuan yang harus dimiliki oleh peserta didik pada dimensi keterampilan (Permendikbud Nomor 20 Tahun 2016).

Integrasi berpikir kritis dan kreatif dalam proses pembelajaran pada kurikulum 2013 tentu beralasan-yaitu sebagai upaya peningkatan kualitas pembelajaran dan kualitas lulusan (Ariyana, 2018). Integrasi berpikir kritis dan kreatif tersebut mengikuti arah kebijakan Kemendikbud bahwasannya pada tahun 2018 telah terintegrasi HOTS selain Penguatan Pendidikan Karakter (PPK). Berdasarkan uraian diatas, sangatlah penting kegiatan ini bagi guru untuk mampu mengintegrasikan HOTS dalam pembelajaran. Kegiatan ini diharapkan menjadi salah satu wadah bagi guru untuk meningkatkan kompetensinya dalam hal pengintegrasian HOTS dalam pembelajaran.

\section{METODE}

Kegiatan pengabdian kepada masyarakat ini terintegrasi dengan program KKN (Kuliah Kerja Nyata) mahasiswa semester Genap 2019/2020 yang dilaksanakan mulai 1-26 Juli 2019. Karena terintegrasi dengan program $\mathrm{KKN}$, maka kegiatan pengabdian kepada masyarakat ini juga dilaksanakan dalam rentang waktu tersebut yakni dilaksanakan pada tanggal 18 Juli 2019.

Kelompok sasaran kegiatan pengabdian kepada masyarakat ini adalah guru-guru sekolah khususnya guru sekolah dasar-dimana lokasi sekolahnya berada dalam wilayah penempatan KKN yakni berada pada beberapa desa di Kecamatan Sepulu, Kecamatan Klampis dan Kecamatan Tanjung Bumi, Kabupaten Bangkalan. Dengan mempertimbangkan lokasi kelompok sasaran yang tersebar di tiga kecamatan, maka tempat pelaksanaan kegiatan pengabdian kepada masyarakat ini dilaksanakan di UPTD SDN Maneron 1 Kecamatan Sepulu Kabupaten Bangkalan-yang merupakan tengahtengah dari tiga wilayah kecamatan yang merupakan kelompok sasaran kegiatan. Namun tidak semua desa di tiga kecamatan tersebut menjadi lokasi program KKN sehingga kelompok sasaran juga menyesuaikan dengan lokasi program KKN. Adapun desa-desa yang menjadi lokasi program KKN sebagai berikut.

Tabel 1. Lokasi Program KKN

\begin{tabular}{|l|l|l|}
\hline No. & \multicolumn{1}{|c|}{ Nama Desa } & \multicolumn{1}{|c|}{ Kecamatan } \\
\hline 1. & Desa Maneron & Sepulu \\
\hline 2. & Desa Banyior & Sepulu \\
\hline 3. & Desa Prancak & Sepulu \\
\hline
\end{tabular}




\begin{tabular}{|l|l|l|}
\hline 4. & Desa Bumi Anyar & Tanjung Bumi \\
\hline 5. & Desa Tambak Pocok & Tanjung Bumi \\
\hline 6. & Desa Aeng Taber & Tanjung Bumi \\
\hline 7. & Desa Tagungguh & Tanjung Bumi \\
\hline 8. & Desa Ko'ol & Klampis \\
\hline 9. & Desa Larangan Glintong & Klampis \\
\hline 10. & Desa Lergunong & Klampis \\
\hline
\end{tabular}

Dengan pertimbangan lokasi KKN, kelompok sasaran dikhususkan untuk sekolah dasar-sekolah yang berada dalam wilayah lokasi KKN. Adapun sekolah yang menjadi kelompok sasaran dalam kegiatan ini secara terperinci sebagai berikut.

Tabel 2. Kelompok Sasaran KKN-Abdimas

\begin{tabular}{|l|l|l|}
\hline No. & \multicolumn{1}{|c|}{ Nama Sekolah } & \multicolumn{1}{|c|}{ Kecamatan } \\
\hline 1. & UPTD SDN Maneron 1 & Sepulu \\
\hline 2. & UPTD SDN Maneron 2 & Sepulu \\
\hline 3. & UPTD SDN Maneron 3 & Sepulu \\
\hline 4. & UPTD SDN Banyior 1 & Sepulu \\
\hline 5. & UPTD SDN Banyior 2 & Sepulu \\
\hline 6. & UPTD SDN Prancak 1 & Sepulu \\
\hline 7. & UPTD SDN Prancak 2 & Sepulu \\
\hline 8. & UPTD SDN Bumi anyar 1 & Tanjung Bumi \\
\hline 9. & UPTD SDN Bumi Anyar 2 & Tanjung Bumi \\
\hline 10. & UPTD SDN Tambak Pocok & Tanjung Bumi \\
& 1 & \\
\hline 11. & UPTD SDN Tambak Pocok & Tanjung Bumi \\
\hline 12. & UPTD SDN Aeng Taber 1 & Tanjung Bumi \\
\hline 13. & UPTD SDN Aeng Taber 2 & Tanjung Bumi \\
\hline 14. & UPTD SDN Tagungguh 1 & Tanjung Bumi \\
\hline 15. & UPTD SDN Tagungguh 2 & Tanjung Bumi \\
\hline 16. & UPTD SDN Tagungguh 3 & Tanjung Bumi \\
\hline 17. & UPTD SDN Tagungguh 4 & Tanjung Bumi \\
\hline 18. & UPTD SDN Ko’ol & Klampis \\
\hline 19. & UPTD SDN Larangan & Klampis \\
& Glintong 1 & \\
\hline 20. & UPTD SDN Larangan & Klampis \\
& Glintong 2 & \\
\hline 21. & UPTD SDN Larangan & Klampis \\
& Glintong 3 & \\
\hline 22. & UPTD SDN Lergunong 1 & Klampis \\
\hline 23. & UPTD SDN Lergunong 2 & Klampis \\
\hline
\end{tabular}

Kegiatan pengabdian kepada masyarakat ini terdiri atas beberapa tahap yaitu 1) tahap pra pelaksanaan kegiatan; 2) tahap pelaksanaan kegiatan, dan 3) tahap pasca pelaksanaan kegiatan. Tahap pra pelaksanaan kegiatan dilakukan untuk mengidentifikasi masalah dan klarifikasi potensi yang ada di sekolah-sekolah kelompok sasaran. Metode yang digunakan pada tahap ini adalah wawancara dan observasi. Informan pada kegiatan ini adalah guru-guru sekolah-lokasi sekolahnya berada dalam wilayah penugasan KKN di Kecamatan Klampis, Kecamatan Sepulu dan Kecamatan Tanjung
Bumi. Sedangkan observasi dilakukan untuk mengamati kegiatan pembelajaran yang ada di sekolah.

Tahap pelaksanaan kegiatan direalisasikan dalam bentuk workshop dan pelatihan. Metode yang digunakan pada tahap ini adalah ceramah, tanya jawab, dan praktek. Metode ceramah digunakan untuk memberikan informasi terkait kajian teoritis mengenai HOTS. Metode tanya jawab dilakukan untuk menghimpun informasi yang belum diketahui oleh peserta terkait kajian teoritis maupun praktis mengenai HOTS. Sedangkan metode praktek dilakukan untuk melatih peserta menyusun perangkat pembelajaran dan soal berbasis HOTS. Narasumber pada kegiatan tahap ini adalah 1) Umi Hanik, S.Pd., M.Pd memaparkan materi tentang pembelajaran dan penyusunan soal berbasis HOTS, 2) Isna Ida Mardiyana, S.Pd., M.Pd memaparkan materi tentang penyusunan perangkat berbasis HOTS, dan 3) Abdul Rosid, S.Pd., M.Pd memaparkan materi terkair revisi kurikulum 2013.

Sedangkan pada tahap pasca pelaksanaan kegiatan, digunakan metode pendampingan intensif secara online melalui grup whatsapp. Untuk mempermudah penyampaian informasi, kegiatan pengabdian kepada masyarakat ini menggunakan media berupa 1) modul pelatihan, dan 2) bahan presentasi dalam bentuk powerpoint.

\section{HASIL DAN PEMBAHASAN}

Kegiatan KKN merupakan kegiatan lapangan bagi mahasiswa yang menempuh program pendidikan S-1 di Universitas Trunojoyo Madura (UTM). Sedangkan kegiatan pengabdian kepada masyarakat merupakan salah satu kegiatan Tridarma Perguruan Tinggi, dimana kegiatan tersebut digunakan oleh civitas akademika UTM untuk menunjukkan peran aktifnya dalam pembangunan pada wilayah terdekat dengan UTM yaitu Pulau Madura. Dua kegiatan ini disinergikan oleh Lembaga Penelitian dan Pengabdian kepada Masyarakat (LPPM) UTM dalam satu kegiatan yaitu Kuliah Kerja NyataPengabdian kepada Masyarakat (KKN-Abdimas) (LPPM UTM, 2019).

Kegiatan pengabdian kepada masyarakat yang bertujuan untuk meningkatkan kompetensi guru dalam mengintegrasikan HOTS pada pembelajaran telah dilakukan sesuai dengan metode pelaksanaan yang direncanakan. Kegiatan terdiri atas 3 (tiga) tahap dan 
menghasilkan beberapa capaian diantaranya sebagai berikut. Pada tahap pra pelaksanaan kegiatan, telah berhasil diidentifikasi masalah terkait implementasi kurikulum 2013 dalam mengintegrasikan HOTS. Masalah yang muncul di sekolah-sekolah kelompok sasaran diantaranya 1) beberapa sekolah belum siap mengimplementasikan kurikulum 2013 sehingga terkait beberapa komponen - salah satunya HOTS yang harus diintegrasikan dalam kurikulum belum sepenuhnya dipahami, dan 2) bantuan dari Kementerian Pendidikan dan Kebudayaan berupa Pendampingan Kurikulum 2013 belum diterima oleh sebagian besar sekolah termasuk sekolah yang menjadi kelompok sasaran. Hal ini menjadi permasalahan tersendiri karena berdasarkan himbauan dari Kemdikbud mulai tahun ajaran 2018/2019 semua sekolah wajib mengimplementasikan kurikulum 2013 (Kemendikbud, 2018) meskipun dasar kebijakannya mengatakan bahwa "Satuan pendidikan dasar dan menengah dapat melaksanakan Kurikulum Tahun 2006 paling lama sampai dengan tahun pelajaran 2019/2020" (Permendikbud No. 160 Tahun 2014).

Sedangkan pada tahap pelaksanaan kegiatan telah berhasil dicapai peningkatan pengetahuan dan pemahaman peserta yang ditandai dengan berhasilnya peserta menyusun soal berbasis HOTS untuk beberapa muatan mata pelajaran seperti 1) matematika, 2) ilmu pengetahuan alam, dan 3) ilmu pengetahuan sosial sebesar $71 \%$. Selain itu, respon peserta tergolong relatif baik yang terlihat dari keaktifan peserta dalam bertanya, menjawab pertanyaan dan praktik penyusunan soal berbasis HOTS. Hal ini disebabkan karena tingkat kebutuhan atau kepentingan para guru terkait adanya keharusan memiliki kompetensi mengimplementasikan kurikulum 2013 dengan mengintegrasikan beberapa unsur salah satunya HOTS.

Terdapat beberapa kendala pada tahap pelaksanaan kegiatan yakni, pertama, lokasilokasi sekolah kelompok sasaran dengan lokasi kegiatan tergolong relatif jauh meskipun berada dalam satu kecamatan. Kedua, terbatasnya jumlah guru di tiap sekolah sehingga tidak ada guru pengganti untuk mengajar. Hal tersebut menyebabkan beberapa sekolah yang telah diundang tidak dapat menghadiri kegiatan workshop dan pelatihan ini. Kondisi ini diprediksikan juga terjadi pada kegiatan atau program lain yang serupa. Hal ini semakin meneguhkan kondisi bahwasannya masih banyak persiapan-persiapan yang harus dilakukan untuk mengimplementasikan kurikulum 2013 baik berupa suprastruktur maupun infrastruktur. Termasuk dalam hal ini menyiapkan kompetensi guru karena guru adalah garda terdepan untuk mengimplementasikan kurikulum 2013 yang tercermin dalam pembelajaran di kelas.

Sedangkan pada tahap pasca pelaksanaan kegiatan, dilakukan pendampingan secara daring (online) melalui grup whatsapp. Pada tahap ini peserta didampingi secara intensif untuk menyusun perangkat pembelajaran berbasis HOTS. Hasil dari kegiatan pada tahap ini adalah kemampuan peserta dalam menyusun perangkat pembelajaran berbasis HOTS. Kendala yang ditemui pada tahap ini yakni keaktifan peserta untuk melakukan konsultasi secara berkelanjutan sebesar 17\%. Angka ini termasuk dalam kategori rendah. Salah satu faktor penyebabnya adalah para peserta sudah kembali pada instansinya masing-masing sehingga kembali disibukkan dengan rutinitas harian seperti mengajar.

\section{KESIMPULAN}

Dari sisi proses, hasil kegiatan dapat disimpulkan termasuk dalam kategori baik dengan indikator diantaranya: 1) 65\% kelompok sasaran yang diwakili oleh guru dapat berpartisipasi dalam kegiatan, dan 2) respon peserta sangat antusias dalam mengikuti workshop dan pelatihan. Sedangkan dari sisi hasil termasuk dalam kategori kurang meskipun dalam tahap pelaksanaan peserta antusias dengan melakukan praktek penyusunan soal berbasis HOTS namun respon peserta kurang pada tahap pendampingan penyusunan perangkat pembelajaran, yakni sebesar $17 \%$. Hal ini akan dijadikan sebagai bahan evaluasi terkait pemilihan metode untuk setiap kegiatan. Namun dengan melihat antusiasme peserta dalam mengikuti kegiatan workshop dan pelatihan dan tingkat kebutuhan dan kepentingan peserta terhadap implementasi kurikulum 2013 khususnya dalam mengintegrasikan beberapa unsur salah satunya HOTS maka perlu diadakan kegiatan-kegiatan serupa.

\section{DAFTAR PUSTAKA}

Ariyana, Y. 2018. Buku Pegangan Pembelajaran Berorientasi pada Keterampilan Berpikir Tingkat Tinggi. Tanpa kota: Direktorat Jenderal Guru dan Tenaga Kependidikan Kemendikbud. 
Heong, Y. M. 2011. The Level of Marzano Higher Order Thinking Skills Among Technical Education Students. International Journal of Social And Humanity. Vol 1. No 2. 121-125 pp.

Johnson, E.B. 2002. Contextual Teaching And Learning: Menjadikan Kegiatan Belajar Mengajar Mengasyikan Dan Bermakna. Terjemahan oleh Ibnu Setiawan. California: MLC

Kemendikbud, 2017. Modul Penyusunan Higher Order Thinking Skill (HOTS). Jakarta: Direktort Jenderal Pendidikan Dasar dan Menengah Departeman Pendidikan dan Kebudayaan.

Kemendikbud. 2018. Kemendikbud Berikan Bantuan Pendampingan Kurikulum 2013. Diakses 18 September 2019, pukul 02.05 WIB). Tersedia pada https://www.kemendikbud.go.id

LPPM UTM. 2019. Panduan Pelaksanaan Hibah Pengabdian kepada Masyarakat. Bangkalan: -

Peraturan Menteri Pendidikan dan Kebudayaan No 22 Tahun 2016 tentang Standar Proses Pendidikan Dasar dan Menengah (Berita Negara
Republik Indonesia Tahun 2016 Nomor 955).

Permendikbud Nomor 160 Tahun 2014 tentang Pemberlakuan Kurikulum Tahun 2006 dan Kurikulum 2013 (Berita Negara Republik Indonesia Tahun 2014 Nomor 1902).

Siswono, T.Y.E. 2018. Pembelajaran Matematika Berbasis Pengajuan Masalah: Fokus pada Berpikir Kritis dan Berpikir Kreatif. Bandung: Rosda Karya.

Subagiyo, L \& Safrudiannur. 2014. Implementasi Kurikulum 2013 pada Jenjang SD, SMP, SMA, dan SMK di Kalimantan Timur Tahun 2013/2014. Pancaran. Vol 3. No 4. 131-144 pp.

Wahyuni, F. 2015. Kurikulum dari Masa ke Masa. Al-Adabiya. Vol 10. No 2. 231$242 \mathrm{pp}$.

Wisudawati, A. 2017. Problematika dalam Penerapan Penilaian Kurikulum 2013 Bagi Guru di SD Muhammadiyah 24 Surakarta.

Surakarta. 